Author version: Nat. Hazards, vol.63; 2012; 1515-1525

\title{
Intensification of Aila ( May2009) due to a warm core eddy in the north Bay of Bengal
}

\author{
Y.Sadhuram*, K.Maneesha and T.V.Ramana Murty \\ National Institute of Oceanography, Regional Centre (CSIR), \\ D.No.8-44-1/5, China waltair, Visakhapatnam -530003 \\ E-mail: sadhuram@nio.org
}

\begin{abstract}
A very severe cyclonic storm "Aila" hit West Bengal on $26^{\text {th }}$ May 2009.The storm intensified when it encountered with a warm core $\left(\mathrm{SST}=31^{\circ} \mathrm{C}\right)$ anti cyclonic eddy $(\mathrm{ACE})$ in the north Bay of Bengal. The storm intensity increased by $43 \%$ due to this eddy which is comparable with that (34\%) obtained from a best fit line( derived from several numerical experiments over north west Pacific Ocean).The shallow mixed layer of the large scale ocean and deep mixed layer inside the eddy appear to be crucial parameters besides translation speed of the storm (Uh), ambient relative humidity and thermal stratification below mixed layer, in the storm intensification. From the eddy size and Uh, the eddy feed back factor is found to be about 0.4 (i.e $40 \%$ ) which is close to the above.. The upper ocean heat content (UOHC) in the eddy is very high $\left(149 \mathrm{kj} / \mathrm{cm}^{2} ; 300 \%\right.$ higher than the climatological value). This high UOHC opposes the cooling due to the storm interaction and entrainment of waters below thermocline and provides large enthalpy (latent + sensible) flux and helps in the storm intensification. To our knowledge, this is the first study to show the effect of a warm eddy on storm intensification in the Bay of Bengal .
\end{abstract}

Key words: Aila, Bay of Bengal, upper ocean heat content, warm eddy, mixed layer 


\section{Introduction}

It is a well known fact that the frequency of cyclones is 3-4 times higher over Bay of Bengal compared with the Arabian sea. Most of these storms generally move in west north westerly direction and some take recurve and hit Bangladesh. In addition to atmospheric parameters, it is now realized that the upper ocean heat content (UOHC) and the vertical thermal structure play a vital role in the intensification of storms rather than sea surface temperature (SST). Studies on hurricanes ( Opal,1995; Mitch,1998;Bret , 1998) in the Atlantic and super typhoon (Maemi,2003) in the north west Pacific Ocean showed that the storms intensified when they moved over warm eddies (Shay et.al, 2000; Goni and Trinanes, 2003; Lin et.al, 2005;2008; Wu et.al, 2007) Hurricane Katrina intensified from category 1 to 5 while passing over warm loop current ( Scharroo et.al, 2005 ). Maemi intensified by 138\% when it encountered with a warm eddy. It was found that the models underestimate the intensity of storms by $26-30 \%$ when the eddies are not considered (Lin et.al,2005). Wu et.al (2007) studied the role of eddies through numerical experiments for north west Pacific Ocean and suggested a best fit line with eight parameters [viz; sea surface temperature inside eddy (SST eddy); SST of large scale ocean; mixed layer of the large scale ocean (MLD) and inside the eddy (MLD eddy ); ambient relative humidity (R.H.), storm size, stratification below mixed layer, and the translation speed of the storm (Uh)] and found a very high correlation $(=0.97)$ with model results. Rapid intensification of Nargis over warm ocean region was observed due to high enthalpy flux (latent+sensible) ( 300\% higher than climatological) and UOHC ( $77-105 \mathrm{kj} / \mathrm{cm}^{2}$ ) ( Lin et al 2009). Hence monitoring of eddies, upper thermal structure of the ocean (through the depth of $26^{\circ} \mathrm{C}$ isotherm, D26) and areas of high UOHC gained importance in forecasting the intensity of storms.

Even though Bay of Bengal is well known for eddies (Ali et.al, 1998; Gopalan et.al, 2000), the role of these eddies in the intensification of a storms is not clearly known. Sadhuram et.al (2004) studied the variability of UOHC ( it was termed as 'cyclone heat potential') and found that it was more than 58 $\mathrm{kj} / \mathrm{cm}^{2}$ in the Andaman sea, central and southern Bay of Bengal where the cyclones frequently generate and intensify during the post -monsoon season (October-November). Simple relationships to estimate D26 \& UOHC from sea surface height Anomalies (SSHA) have been suggested for Bay of Bengal. It was found that the method suggested by Shay et.al (2000) underestimate UOHC in anti cyclonic eddy (ACE) in the Bay of Bengal (Sadhuram et.al, 2006). Importance of the meso scale eddies in the distribution of UOHC are very sparse in Bay of Bengal. The UOHC is almost double $\left(125 \mathrm{kj} / \mathrm{cm}^{2}\right)$ in 
anti cyclonic eddy (ACE) compared with that $\left(67 \mathrm{kj} / \mathrm{cm}^{2}\right)$ in a cyclonic eddy (CE) during pre-monsoon (May, 1996) season in Bay of Bengal (Sadhuram et.al, 2004). The role of SSHA and eddies in the intensity of cyclones in Bay of Bengal had been discussed by Ali et.al (2007). Many studies ( Lin et.al, 2005,2008; Wu et.al, 2007 ) over the north west Pacific Ocean brought out the vital role of UOHC and warm eddies in the intensity and movement of severe cyclones. Similar studies over Bay of Bengal are not available sofar.

Using the in situ CTD measurements from the research vessel, UOHC and D26 are estimated for a few eddies in Bay of Bengal. The locations of the eddies for different periods are shown in Fig.1.There were only 2 ACEs and 6 CEs. One can see large a variability in UOHC \& D26 between ACE and CE. Though CE3\&CE6 are located at the same place, UOHC is almost double in CE6 compared with that in CE3. This was due to the fact that CE3 was present in southwest monsoon season (July, 2001) while CE6 was in the pre-monsoon season (April, 2003). Thus it could be inferred that both the quantities (UOHC \&D26) are highly variable with CE and ACE. The average of UOHC is 103 $\mathrm{kj} / \mathrm{cm}^{2}$ in ACE while it is only $35 \mathrm{kj} / \mathrm{cm}^{2}$. Similarly, D26 is $102 \mathrm{~m}$ and $37 \mathrm{~m}$ in ACE and CE respectively. This shows that both the quantities are almost 3 times higher in ACE compared with that in CE (Table.1). When a storm moves over ACE it is likely to intensify and weakens if it moves over a CE. It is known that these eddies are highly variable with space and time. There were some occasions where the storm is expected to intensify but weakens over the sea (due to a cold core CE) before crossing the coast .Since not much attention is paid towards these eddies, people expect that the storm will intensify further and cross the coast. Accordingly an alert will be given to public. Thus there is a possibility for wrong forecast.

A low pressure area developed in the southern Bay of Bengal on $22^{\text {nd }}$ May 2009 with a sea level pressure of $1007 \mathrm{mb}$. It intensified to a cyclonic storm "Aila" and further intensified as severe cyclonic storm and crossed west Bengal on $26^{\text {th }}$ May 2009 with a storm surge of about 2-3 $\mathrm{m}$ height. This severe storm affected west Bengal and Bangladesh. About 110 people were killed and 2.2 million people were affected. A record rainfall of $260 \mathrm{~mm}$ was observed at Paradeep, Orissa. (www.imd.gov.in).

In this, we have studied the effect of a warm core ACE in the intensification of "Aila", which has not been attempted earlier. Details of data sets and methods are presented in section. 2 . Results and discussion in section. 3 and conclusions in section. 4 are presented . 


\section{Data sets and methods}

A deep depression in the southern Bay of Bengal intensified into a cyclonic storm "Aila" on $24^{\text {th }}$ May 2009 (1200 GMT) at $18.5^{\circ} \mathrm{N} ; 88.5^{\circ}$ E. It further intensified to a very severe cyclone moved in a northerly direction and crossed West Bengal coast on $26^{\text {th }}$ May 2009. Details of Storm track, maximum sustainable wind speed $(\mathrm{m} / \mathrm{sec})$ and central pressures $(\mathrm{mb})$ are taken from the IMD's (India Meteorological Department, New Delhi) website, www.imd.gov.in. The data on sea surface height anomalies (SSHA) for the period 22-24 May 2009 have been taken from Jason-2 data ( www.aviso.oceanobs.com). TMI SST data, Temperature profiles from Argo and RAMA buoys, mean temperature profiles for May 2009 in the Bay of Bengal (http://iridl.ldeo.columbia.edu/ SOURCES/.

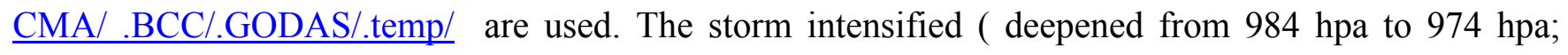
winds reached a maximum intensity of $27 \mathrm{~m} / \mathrm{s})$ when encountered with a warm core $\left(\mathrm{SST}=31^{\circ} \mathrm{C}\right) \mathrm{ACE}$ in the region, $19.5^{\circ}$ to $21 \mathrm{~N} ; 88-89^{\circ} \mathrm{E}$ (north Bay of Bengal) during $24^{\text {th }}-25^{\text {th }}$ May 2009. The contribution of eddy towards the intensification of Aila is estimated following Wu et.al (2007).

The eddy feedback factor, $\mathrm{F}_{\mathrm{EDDY}-\mathrm{T}}$, is defined as

$F_{E D D Y-T}=\frac{\Delta p_{\text {out }}-\Delta p_{\text {in }}}{\Delta p_{\text {in }}}$

Where $\Delta \mathrm{p}_{\text {in }}\left(\Delta \mathrm{p}_{\text {out }}\right)$ is the amount of sea level central pressure deepening at the moment when the storm encounters (leaves) the ocean eddy. The subscript "-T" indicates the TC only passes an ocean eddy for a finite (transient) period. Likewise, $\mathrm{F}_{\text {EDDY-T }}$ could be positive (warm eddy) or negative (cold eddy). From the observed central pressure of the storm , $\mathrm{F}$ eddy- $\mathrm{T}$ is found to be 0.43 . In other words, the intensity of the storm enhanced by $43 \%$ due to this ACE. After conducting several numerical experiments over north west Pacific Ocean, Wu et.al (2007), suggested a best fit line with 8 parameters ( given in section.1) and a very high correlation (0.97) was found between the model results and the following equation (2). 


$$
\begin{aligned}
F_{E D D Y-T}= & 0.38\left(\frac{S S T_{E D D Y}-26^{0} C}{S S T-26^{0} C}\right)^{1.88} \\
& \times\left(S S T_{E D D Y}-26^{0} C\right)^{0.2}\left(M L_{E D D Y}\right)^{0.98} \\
& \times(M L)^{-0.97}(\eta)^{0.22} \\
& \times(1-R H)^{-0.74}(\Gamma)^{0.45}\left(U_{H}\right)^{-0.83}
\end{aligned}
$$

Where SST and mixed layer (ML) represent large scale steady ocean. $\mathrm{SST}_{\text {eddy }}$ and $\mathrm{ML}_{\text {eddy }}$ are inside the eddy, $\eta$ is the storm size , $\mathrm{RH}$ is ambient relative humidity, $\Gamma$ is the thermal stratification below mixed layer and $\mathrm{Uh}$ is the translation speed $(\mathrm{m} / \mathrm{sec})$ of the storm.

\section{Results and discussion}

The distribution of SSHA during 22-24 May 2009 in the Bay of Bengal is shown in Fig.2. A warm core eddy (shown as ACE in Fig.2) with high SSHA of $25 \mathrm{~cm}$ could be seen clearly in the north Bay of Bengal. The track of Aila is shown on the SSHA map of $24^{\text {th }}$ May 2009. Another eddy with a SSHA of more than $20 \mathrm{~cm}$ was present in the southwest Bay of Bengal. Two Argo floats on $22^{\text {nd }}$ and $23^{\text {rd }}$ May 2009 were close to this eddy (shown as squares in Fig.2c). The central pressure was 984 mb just before entering the warm eddy and intensified after crossing the eddy at which the central pressure was $974 \mathrm{mb}$. Wind speed reached a maximum of $27 \mathrm{~m} / \mathrm{sec}$. The storm could be tracked from CDR (Cyclone Detection Radar) at Paradeep and the hourly data on storm positions (www.imd.gov.in) have also been considered to exactly identify the entering and leaving positions of the storm through the eddy. (Fig.3) .The distribution of TMI SST (www.incois.gov.in) during 22-24 May along with the SSHA are shown in Fig.4. SST was varying between $29^{\circ} \mathrm{C}$ to $31^{\circ} \mathrm{C}$ with the maximum over the eddy regions. There were two ACEs, one located in the SW Bay of Bengal $\left(14-15^{\circ} \mathrm{N}: 81-84^{\circ} \mathrm{E}\right)$ and the other in the north Bay of Bengal (indicated as ACE in Fig.2). The warm temperatures during May are quite obvious. The distribution of mixed layer depth (MLD) (m) and the stratification below mixed layer ( $Г$ ) for May 2009 are shown in Fig.5. MLD was varying between 20 to $50 \mathrm{~m}$ over the Bay with a maximum in the southwest Bay of Bengal. There was not much variation in $\Gamma\left({ }^{0} \mathrm{C} / \mathrm{m}\right)$. These values are compared with those estimated from the Argo floats and RAMA buoys (shown in Fig.2c). and the vertical temperature profiles are shown in Fig.6. SST was about $30{ }^{\circ} \mathrm{C}$ and the MLD was varying between 29 and $55 \mathrm{~m}$. The 
maximum value of $55 \mathrm{~m}$ was in the eddy located in the SW Bay of Bengal. Similarly there was not much variation in $\Gamma$. These values during 21-24 May 2009 are well comparable with the mean monthly values of May 2009 presented in Fig.5.

The average values in the study area and in ACE along with the other parameters and the $\mathrm{F}$ eddy computed from eqs $1 \& 2$ are shown in Table.3. $\mathrm{SST}_{\text {eddy }}$ is $31.0^{\circ} \mathrm{C}$ while the large scale SST is $30^{\circ} \mathrm{C}$ (Fig.3). Mean MLD over the Bay of Bengal for May 2009 is 40m (Fig.5a). Unfortunately, no data is available inside the eddy to obtain the ML eddy. An earlier study (Murty et.al, 2000) reported a mixed layer of $56 \mathrm{~m}$ inside ACE1 at $15{ }^{\circ} \mathrm{N} ; 88^{\circ} \mathrm{E}$ (shown in Fig.1) ( which is close to present eddy) during the end of May 1996 from the CTD data.. SSHA was about 23-26 cm which is close to that observed (25 $\mathrm{cm}$ ) in the present eddy (Fig.2). Hence, mixed layer inside the eddy ( $\left.\mathrm{ML}_{\text {eddy }}\right)$ is assumed as $56 \mathrm{~m}$. From the sub surface temperature data from Argo float on 23.5.2009, MLD is found to be 55m which is located in the eddy in SW Bay of Bengal (Fig.2c;Table.2).. Thus it appears to be reasonable to assume $\mathrm{ML}_{\text {eddy }}$ as $56 \mathrm{~m}$.The average value of stratification $(\Gamma)$ is $0.084{ }^{\circ} \mathrm{C} . \mathrm{m}^{-1}$ and the ambient relative humidity (R.H) is taken as 83\%.(daily average at the RAMA buoy) during 22-24 May 2009.Average translation speed of the storm (Uh) is estimated as $4.0 \mathrm{~m} / \mathrm{s}$ over the eddy.. Using these data, the eddy feed back factor $F_{\text {eddy-T }}$ is found to be 0.34 which is close to the observed (0.43) from eq(1). (Table.3). It appears that the best fit line suggested by Wu.et al (2007) based on several numerical experiments relevant to north west Pacific Ocean, may be valid for Bay of Bengal. The eddy feed back is positive(negative) for warm(cold) eddy. As this factor depends on storm's speed, the size of the eddy also plays a role due to the interaction time scale of the eddy and storm. From this, it can be said that the shallow MLD and deep MLD eddy are the crucial parameters in storm intensification, in addition to ambient RH, Uh . and $\Gamma$. The importance of shallow mixed layer, salinity and effective oceanic layer (EOL) in the intensification and movement of storms ( 15-19 October \& 25-29 October ,1999) in Bay of Bengal was emphasized by Subrahmanyam et.al (2005). It is interesting to see that the eddy feed back factor estimated from Uh and eddy size ( $300 \mathrm{~km}$ ) (from Fig. 15 ; Wu et.al, 2007) is about 0.4 which is close to the above estimates.[0.43- observed (eq.1); 0.34- estimated (eq.2)] (Table.3) . It may be mentioned here that the observed $\mathrm{F}$ eddy. in case of Opal,1995 and Maemi, 2003 were 1.19 and 1.38 while they were under estimated $(0.5 \& 0.93)$ by the model (Wu et.al, 2007). Even though the eq. 2 was developed for north Pacific Ocean under different oceanic and atmospheric conditions, it appears to be useful to apply for Bay of Bengal, where absolutely no study of this kind is available sofar. 
By examining the few eddies (ACE/CE) for different periods in Bay of Bengal it is observed that both D26 and UOHC are almost 3 times higher in ACE than in CE (Fig.1:Table.1). This large variability in the above quantities plays an important role in the intensification/weakening of the storms, in addition to the atmospheric parameters.. The warm ACE with high UOHC is expected to provide large enthalpy flux (latent+sensible) which helps to enhance the storm intensification. From Argo data it could be seen that the depth of $26{ }^{\circ} \mathrm{C}$ (D26) is high. UOHC in the eddy (SW Bay of Bengal) is $>140 \mathrm{kj} / \mathrm{cm}^{2}$ (Fig.2(c) \&Table 2).In case of " Aila" which encountered with a warm ACE in the north Bay of Bengal during $24^{\text {th }}$ to $25^{\text {th }}$ May 2009, the central pressure dropped from $984 \mathrm{mb}$ to $974 \mathrm{mb}$ and the sustainable winds reached $20-27 \mathrm{~m} / \mathrm{s}$. (Figs.2\&3). SST is about $30^{\circ} \mathrm{C}$ out side the eddy and $31^{\circ} \mathrm{C}$ inside the eddy (Fig.4). The intensity of Aila enhanced by $43 \%$ due to it's interaction with the warm core ACE. The best fit equation (2) which is based on several numerical experiments for Pacific Ocean (Wu et.al, 2007) showed the feed back factor of $34 \%$ which is close to the observed (43\%) from central pressures (from eq.1) .. From our earlier method (Sadhuram et.al, 2006), UOHC and D26 in the centre of the eddy are

estimated as $149 \mathrm{kj} / \mathrm{cm}^{2}$ (about 300\% higher than the climatological value) and $126 \mathrm{~m}$ respectively which are well comparable with those found in the eddy region in the SW Bay of Bengal (Fig.2(c) \&Table 2) and also in ACE1 (Fig.1:Table.1) during May 1996. Intensification of Nargis due to high UOHC and enthalpy flux was reported earlier ( Mc Phaden et.al, 2009; Lin et.al, 2009). The mixed layer inside the eddy and outside, ambient relative humidity appears to play major role in the intensity of cyclone besides RH, translation speed and stratification below mixed layer. The importance of salinity and shallow mixed layer in cyclone tracks over Bay of Bengal during post-monsoon season was discussed earlier. (Subrahmanyam et.al, 2005). The warm deep layer in the eddy opposes the cooling due to storm interaction and entrainment of waters below thermocline. Hence the high UOHC and warm deep layer in the eddy supports high enthalpy flux and helps for the intensification of storm.

\section{Conclusions}

It is inferred that both UOHC and D26 in ACE is about 3 times higher than in CE in the Bay of Bengal. The severe cyclone "Aila" on $24^{\text {th }}$ May 2009 intensified due to the warm core ACE in the north Bay of Bengal.The estimated eddy feed back factor (0.34) from eq.2 is close to the observed (0.43) even though it is based on the numerical experiments done for Pacific Ocean. $F$ eddy estimated (Fig.15; Wu et.al, 2007) from the eddy size $(300 \mathrm{~km})$ and translation speed $(\mathrm{Uh}=4.0 \mathrm{~m} / \mathrm{sec})$ is about 0.4 and close to the above. The role of eddies in the intensity of cyclones over Bay of Bengal was 
reported earlier by Ali et.al (2007). To our knowledge, this is the first study to show the effect of a warm core $\mathrm{ACE}$ on the intensification of a storm in the Bay of Bengal, quantitatively. However, similar studies for more number of storms are desirable to confirm these results. The present models (Sujatha and Mohanthy,2008; Kotal et.al, 2008) and of IMD to forecast the intensity and track of cyclones over Bay of Bengal do not consider the UOHC or the meso scale eddies. It is suggested that the modelers may try to incorporate these to achieve better results as in Pacific Ocean .

\section{Acknowledgements}

The authors would like to thank Dr.S.R.Shetye, Director, N.I..O., and Dr.V.S.N.Murty, Scientist-inCharge, NIO, Regional centre, Visakhapatnam (CSIR,New Delhi) for their support and encouragement. Mrs.Manisha is thankful to CSIR (Council for Scientific and Industrial Research), New Delhi for providing the Senior Research Fellowship (SRF). Thanks to all the project teams for making the data sets (SSHA,TMI SST, Argo data, RAMA buoys data, monthly mean vertical temperature profiles) available on the websites.

\section{References}

Ali,M.M..,Sharma, R. and Cheney,R.:1998, An atlas of the north Indian Ocean eddies from TOPEX altimeter derived sea surface heights.Spec.Publ.ISRO-.SAC, SP, 69-98, Indian Space Res.Org, Bangalore, India

Ali,M.M., Jagadish, P.S.V.,and Jain,S.:2007, Effect of eddies on Bay of Bengal cyclone intensity EOS Trans , AGU, 88(8), doi: 10.1029/2007EO08001

Goni,G.J.,Kamholtz,S.,Garzole,S. and Olson, D.B.:1996, Dynamics of the Brazil-Halvinas confluence based upon inverted echo sounders and altimetry, J.Geophys.Res., 101(7),16273-16289.

Goni,G.J., and Trinanes,J.A.:2003 , Ocean thermal structure monitoring could aid in the intensity forecast of tropical cyclone, EOS Trans, AGU, 84(51) doi: 10.1029/2003EO510001

Goplan , A.K.S.,Gopala Krishna ,V.V. ,Ali, M.M. and Sharma,R.:2000, Detection of Bay of Bengal eddies from TOPEX and in situ observations, J.Mar.Res., 58,721-734.

Kotal,S.D., Roy Bhowmik,R.S.K., and Kundu,P.K.:2008, Application of statistical-dynamical scheme for real time forecasting of the Bay of Bengal very severe cyclonic storm "sidr" of November 2007, Geofizika, 25(2),139-158 
Lin, I-I, Wu,C.C.,Emmanuel, K.A., Lee,I.H., Wu,C.R., and Pun,I.F.:2005, The interaction of super typhoon Maemi (2003) with a warm ocean eddy. Mon.Wea.Rev., 133,2635-2649

Lin,I-I., Wu,C.C., and Pun,I.F.: 2008, Upper ocean thermal structure and the western North Pacific category 5 typhoons, Part I: Ocean features and category 5 Typhoon's intensification, Mon.Wea.Rev., 136,3288-3306

Lin,I-I., Chen,C.H., Pun,I.F.,Liu,W.T., and Wu,C.C., 2009, Warm ocean anomaly, Air-sea fluxes and the rapid intensification of tropical cyclone Nargis, 2008., Geophys.Res.Letts., 36,LO3817,doi:10.1029/2008GL035815

McPhaden, M.J., Foltz,G.R.,Lee,T.,Murty,V.S.N., Ravindran ,M.,Vecchi, G.A., Vialard ,J., Wiggert,J.D., and Yu,L.:2009, Ocean-atmosphere interactions during cyclone Nargis, EOS, Trans., 90(7),53-60

Murthy ,V.S.N., Guptha,G.V.M.,Sarma,V.V.,Rao.B.P.,Jyothi,D.,Shastri,P.N.M. and Supraveena, Y.:2000, Effect of vertical stability and circulation on the depth of chlorophyll maximum in the Bay of Bengal during May-June, 1996, Deep Sea Res., 47(5), 103-117.

Sadhuram,Y.,Rao.B.P.,Shastri,P.N.M and Subrahmanyam,M.V.:2004, Seasonal variability of cyclone heat potential in the Bay of Bengal, Nat.Hazards, 32,191-209

Sadhuram,Y., Ramana Murty,T.V.,and Somayajulu,Y.K.:2006, Estimation of cyclone heat potential in the Bay of Bengal and it's role in the genesis and intensification of the storms in Bay of Bengal, Ind.J.Mar.Sci., 35(2),132-138

Scharroo, R., Smith, W.H.F.,and Lillibridge, J.L.:2005, Satellite altimetry and the intensification of hurricane Katrina, EOS. Trans. Amer.Geophys. Union, 86,366-367

Shay, L.K.,Goni,G.J., and Black ,P.G.:2000, Effects of warm oceanic feature on hurricane Opal .Mon.Wea.Rev., 128,1366-1383

Sujatha,P. and Mohanthy, U.C.:2008, A comparative study on performance of MM5 and WRF models in simulation of tropical cyclones over Indian seas, Curr.Sci., 95 (7), 923-936

Wu,C.C., Lee,C.Y. and Lin,I-I.:2007, The effect of the ocean eddy on tropical cyclone intensity, J.Atmos.Sci., 64,3562-3578 
Table.1. Variability of D26 (m) and UOHC $\left(\mathrm{kj} / \mathrm{cm}^{2}\right)$ in the eddies (shown in fig.1)

\begin{tabular}{|c|c|c|c|c|}
\hline S.No & Date & Eddy & D26 & UOHC \\
\hline 1 & $28 / 05 / 96$ & ACE1 & 130 & 125 \\
\hline 2 & $19 / 4 / 2003$ & ACE2 & 074 & 081 \\
\hline & & average & $\mathbf{1 0 2}$ & $\mathbf{1 0 3}$ \\
\hline 1 & $9 / 06 / 96$ & CE1 & 060 & 067 \\
\hline 2 & $13 / 07 / 01$ & CE2 & 019 & 018 \\
\hline 3 & $26 / 07 / 01$ & CE3 & 027 & 023 \\
\hline 4 & $18 / 09 / 02$ & CE4 & 040 & 028 \\
\hline 5 & $25 / 09 / 02$ & CE5 & 032 & 030 \\
\hline 6 & $30 / 04 / 03$ & CE6 & 042 & 043 \\
\hline & & average & $\mathbf{0 3 7}$ & $\mathbf{0 3 5}$ \\
\hline
\end{tabular}

Table.2. Different parameters derived from Argo and RAMA buoy profiles

\begin{tabular}{|c|c|c|c|c|c|c|c|c|c|c|}
\hline \multirow[b]{3}{*}{ Parameter/Date } & \multirow{2}{*}{\multicolumn{4}{|c|}{ Argo }} & \multicolumn{6}{|c|}{ RAMA Buoys } \\
\hline & & & & & $15^{0} \mathrm{~N}$ & & & $22^{0} \mathrm{~N} 90$ & & \\
\hline & $21 / 5$ & $21 / 5$ & $22 / 5$ & $23 / 5$ & $22 / 5$ & $23 / 5$ & $24 / 5$ & $22 / 5$ & $23 / 5$ & $24 / 5$ \\
\hline $\operatorname{SST}\left({ }^{0} \mathrm{C}\right)$ & 30.59 & 30.90 & 31.21 & 30.52 & 30.52 & 30.18 & 29.85 & 30.13 & 29.81 & 29.66 \\
\hline MLD(m) & 36 & 32 & 36 & 55 & 29 & 29 & 29 & 29 & 29 & 29 \\
\hline$\Gamma\left({ }^{\mathbf{0}} \mathbf{C} \backslash \mathbf{m}\right)$ & 0.083 & 0.080 & 0.078 & 0.082 & 0.091 & 0.09 & 0.089 & 0.081 & 0.082 & 0.082 \\
\hline D26 (m) & 85 & 70 & 127 & 109 & 83 & 79 & 80 & 80 & 82 & 79 \\
\hline D20 (m) & 122 & 125 & 166 & 155 & 122 & 118 & 116 & 118 & 113 & 115 \\
\hline UOHC $\left(\mathrm{Kj} / \mathrm{cm}^{2}\right)$ & 111 & 97 & 149 & 147 & 118 & 106 & 103 & 99 & 96 & 94 \\
\hline
\end{tabular}


Table.3. Details of parameters and the data used in the best fit equation (2) (Wu. et al, 2007)

\begin{tabular}{|c|c|c|}
\hline S.No & parameter & value \\
\hline 1 & SST $\left({ }^{\circ} \mathrm{C}\right)$ & 30.0 \\
\hline 2 & $\mathrm{SST}_{\text {eddy }}\left({ }^{\circ} \mathrm{C}\right)$ & 31.0 \\
\hline 3 & ML (large scale ocean) (m) & 40 \\
\hline 4 & $\mathrm{ML}_{\text {eddy }(\mathrm{m})}$ & 56 \\
\hline 5 & Ambient RH (\%) & 83 \\
\hline 6 & Storm size $(\eta)$ & 0.3 \\
\hline 7 & $\begin{array}{l}\text { Thermal stratification } \\
\text { below mixed layer }(\Gamma) \\
\left({ }^{\circ} \mathrm{C} \cdot \mathrm{m}^{-1}\right)\end{array}$ & 0.084 \\
\hline \multirow[t]{3}{*}{8} & $\begin{array}{l}\text { Translation speed of the } \\
\text { storm (Uh) }(\mathrm{m} / \mathrm{s})\end{array}$ & 4.0 \\
\hline & $\mathrm{F}_{\text {eddy-T }}$ ( observed-eq.1) & 0.43 \\
\hline & $\mathrm{F}_{\text {eddy-T }}$ (estimated-eq.2) & 0.34 \\
\hline
\end{tabular}




\section{Figure captions}

Figure.1 Meso scale eddies (ACE-anti cyclonic: CE cyclonic) in the Bay of Bengal during different periods

Figure.2.Sea Surface Height Anomalies (SSHA)(cm) during (a) 22-05-09 b) 23-05-09 and (c) 24-0509.Track of 'Aila is shown in Fig.2.(c).Positions of Argo floats (Squares )and Rama Buoys (stars) are also shown in Fig.2.(c).warm core eddy is indicated as ACE

Figure.3. Central pressure $(\mathrm{mb})$ and wind speed $(\mathrm{m} / \mathrm{sec})$ of 'Aila' during $23^{\text {rd }}-26^{\text {th }} 2009$. The positions of the storm entering and leaving the warm eddy shown $(\bullet)$.

Figure.4 Sea Surface Height Anomalies $(\mathrm{SSHA})(\mathrm{cm})$ and Sea Surface Temperature $\left({ }^{0} \mathrm{C}\right)$ (contours are drawn at $0.5{ }^{\circ} \mathrm{C}$ interval) during (a) 22-05-09 (b) 23-05-09 and (c) 24-05-09.

Figure.5. Distribution of Mixed Layer Depth (MLD) (m) and (b) Stratification factor $(\Gamma)\left({ }^{0} \mathrm{C} / \mathrm{m}\right)$ during May 2009 in the Bay Of Bengal.

Figure.6 Vertical temperature profiles at (a) $12^{\circ} \mathrm{N} ; 90^{\circ} \mathrm{E}$ (b) $15^{\circ} \mathrm{N} ; 90^{\circ} \mathrm{E}$ from RAMA buoys and (c) from Argo floats during 21- 24 May 2009 


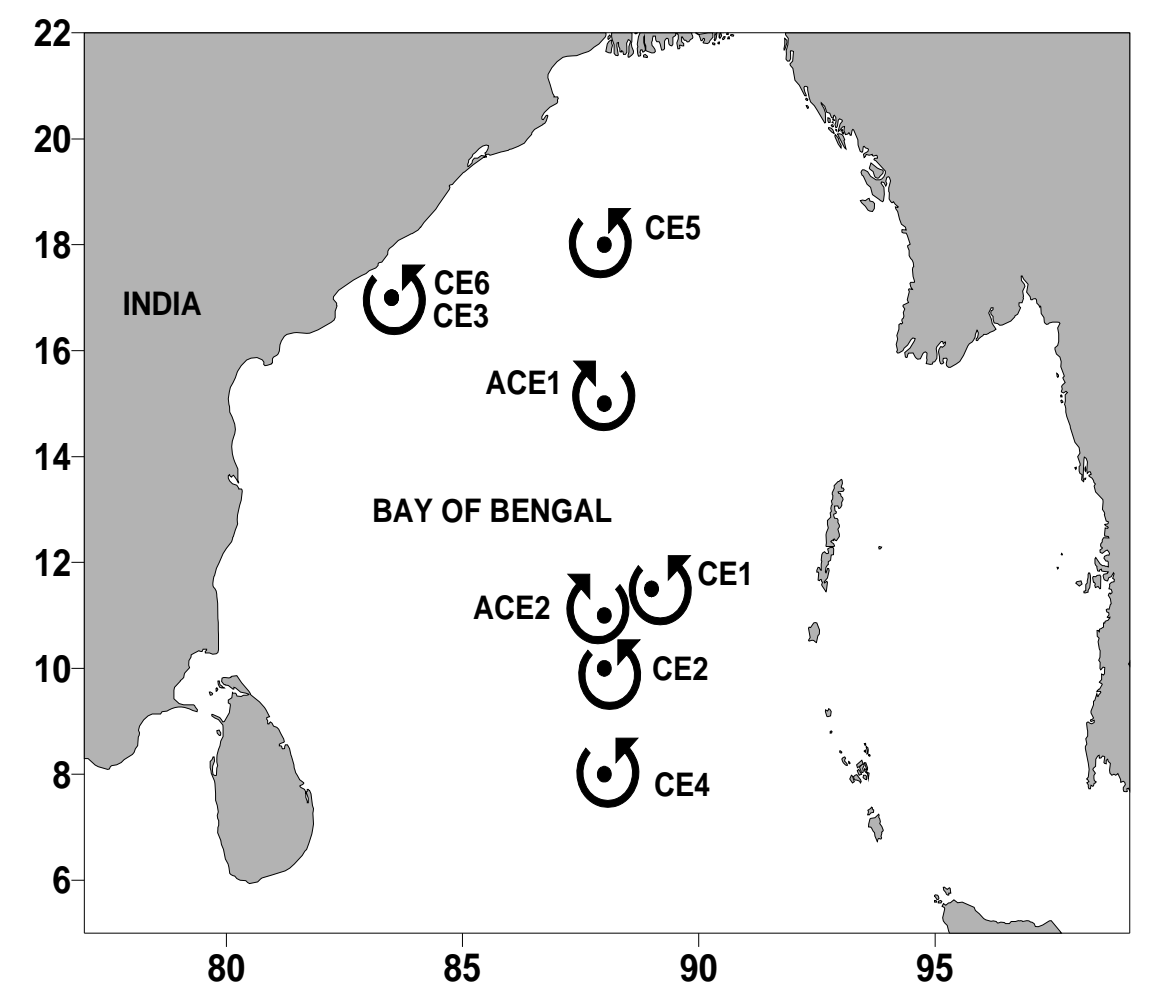

Fig. 1. Meso scale eddies (ACE-anticyclonic Eddy; CE-Cyclonic Eddy) in the Bay of Bengal during different periods 

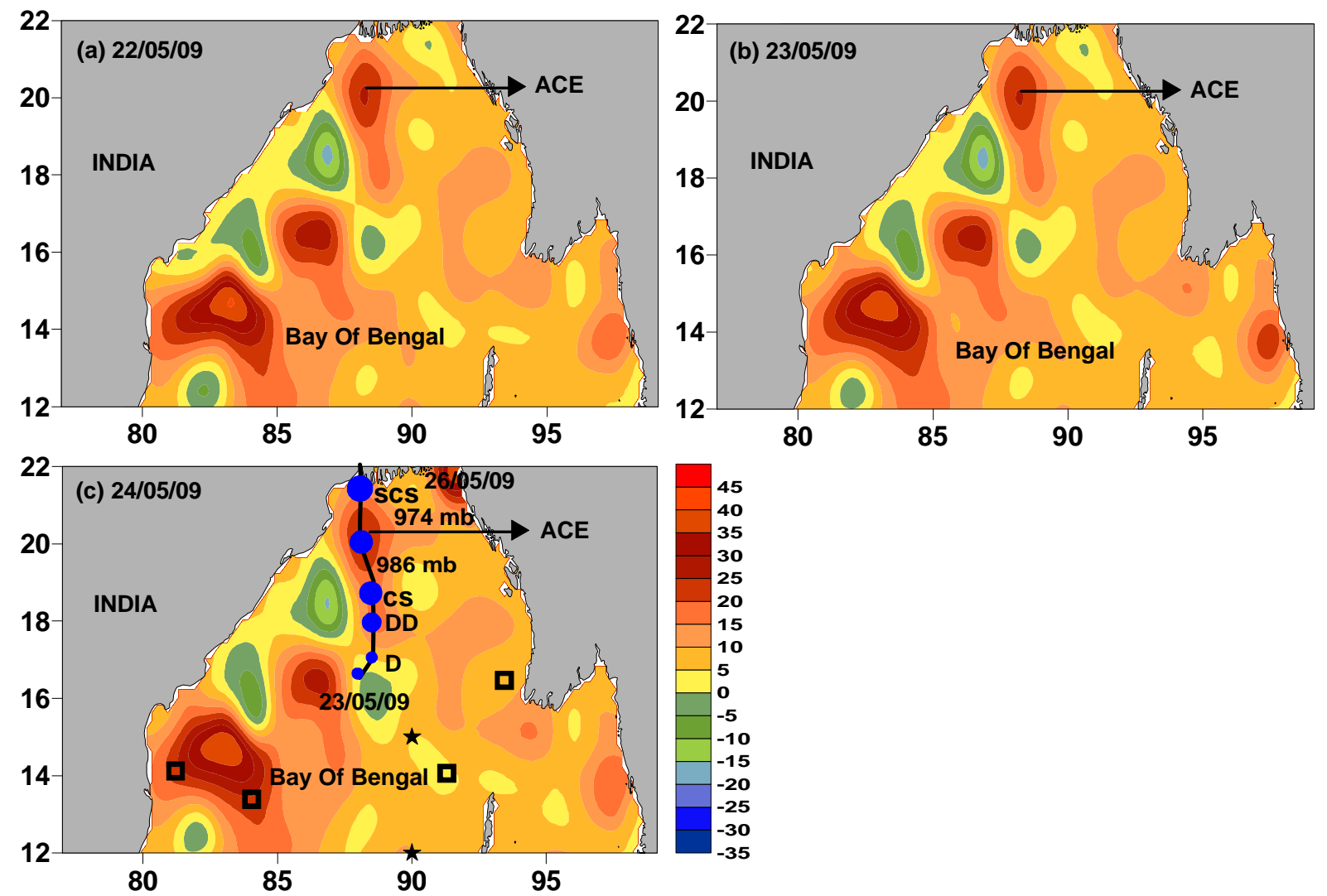

Fig.2.Sea Surface Height Anomalies (SSHA)(cm) during (a) 22-05-09 (b) 23-05-09 and (c) 24-0509.Track of 'Aila is shown in Fig.2.(c).Positions of Argo floats( Squares )and Rama Buoys (stars) are also shown in Fig.2.(c). 


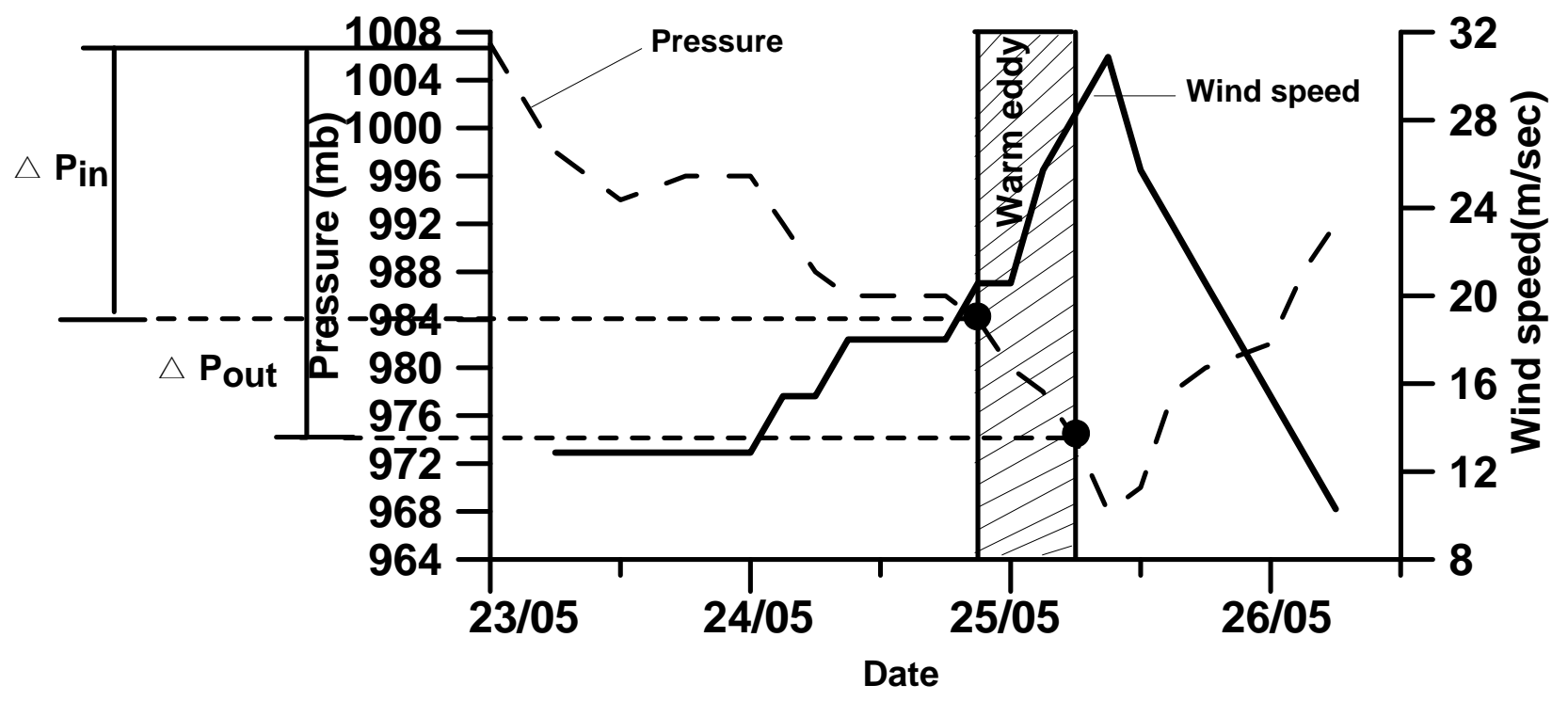

Fig.3. Central pressure $(\mathrm{mb})$ and wind speed $(\mathrm{m} / \mathrm{sec})$ of 'Aila' during $23^{\text {rd }}-26^{\text {th }}$ May 2009 . The positions of the storm entering and leaving the warm eddy are $\operatorname{shown}(\bullet)$. 

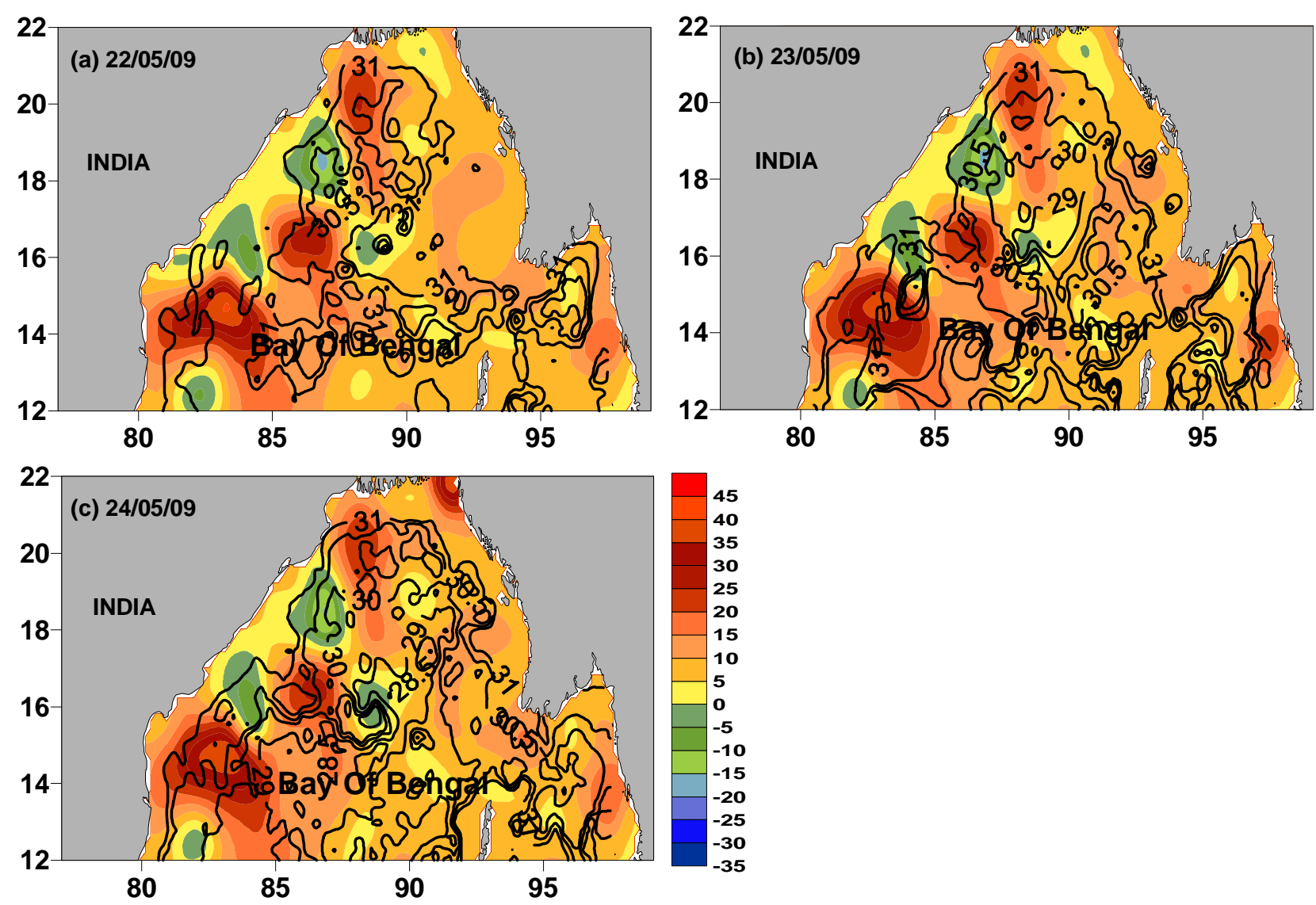

Fig.4. Sea Surface Height Anomalies (SSHA) $(\mathrm{cm})$ and Sea Surface Temperature $\left({ }^{0} \mathrm{C}\right)$ (contours are drawn at $0.5^{\circ} \mathrm{C}$ interval ) during (a) 22-05-09 (b) 23-05-09 and (c) 24-05-09. 

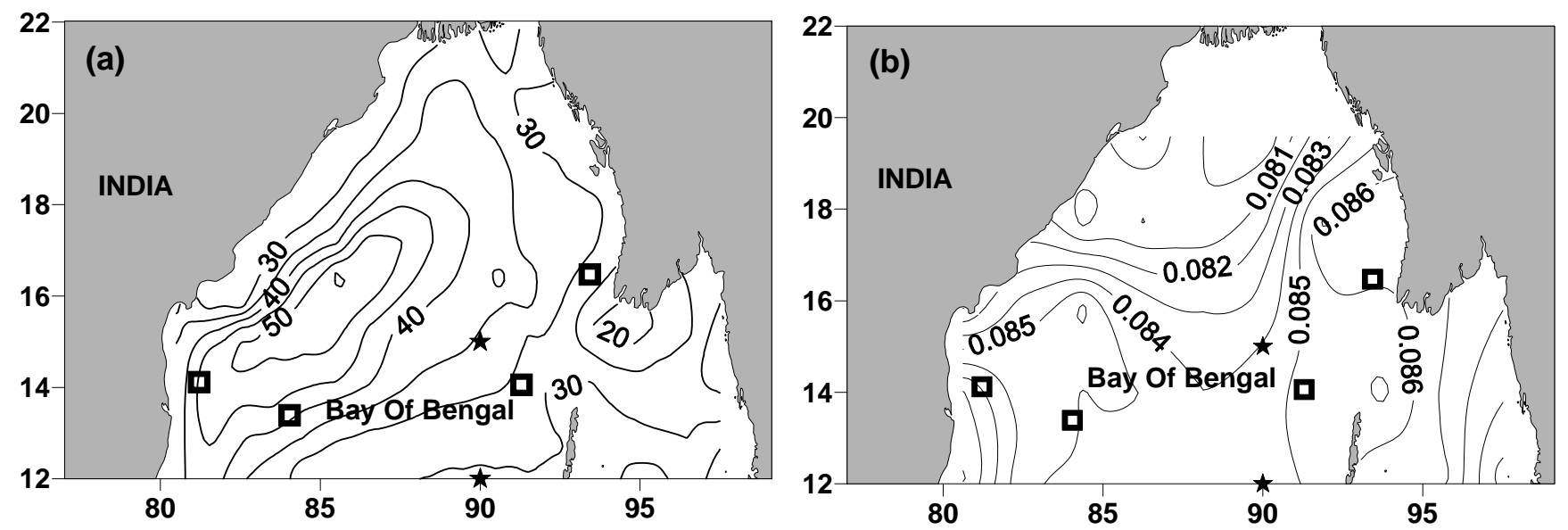

Fig.5. Distribution of Mixed Layer Depth (MLD) (m) and (b) Stratification below mixed layer $(\Gamma)\left({ }^{0} \mathrm{C} / \mathrm{m}\right)$ in the Bay of Bengal during May 2009. 


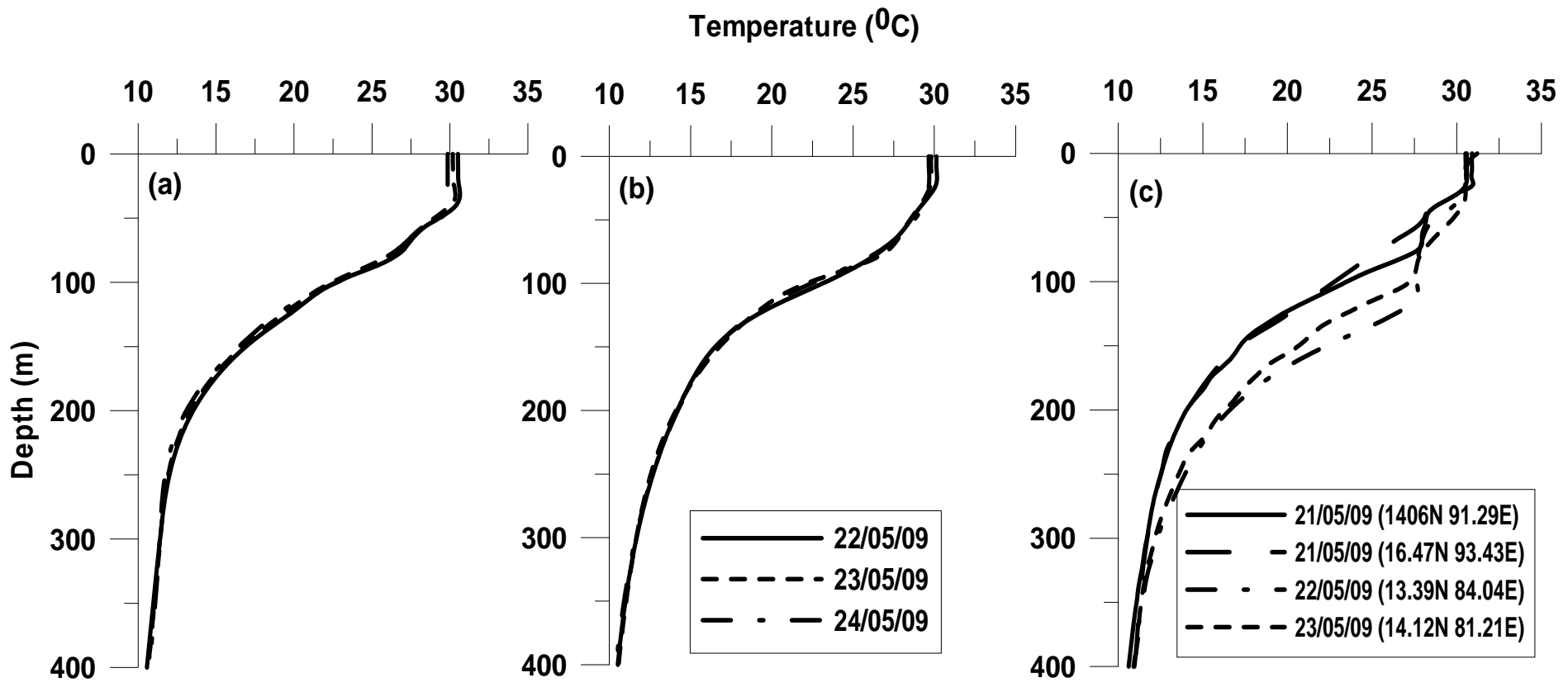

Fig.6. Vertical temperature profiles $\left({ }^{0} \mathrm{C}\right.$ ) at (a) $12^{0} \mathrm{~N} ; 90^{0} \mathrm{E}$ (b) $15^{0} \mathrm{~N} ; 90^{\circ} \mathrm{E}$ from RAMA buoys and (c) Argo floats . 